\title{
Evaluation of chemical and microbial quality of food in northern Iran
}

\author{
Zahra Aghalari ${ }^{1}$, Seyed Reza Hosseini', Somayeh Jafarian² ${ }^{2 *}$, Mohsen Rezazadeh ${ }^{3}$, Mohsen Mirzaei ${ }^{4}$, \\ Ebrahim Esmaeili ${ }^{3}$ and Peyman Hasanzadeh ${ }^{3}$
}

\begin{abstract}
Background: Iran is one of the developing countries and foodborne diseases commonly impose problems for public health, the health care system and the economy. Therefore, this study aimed to evaluate the chemical and microbial quality of food in northern Iran.
\end{abstract}

Methods: This cross-sectional study was conducted in 2019. This study was performed on food samples obtained in a straightforward way while visiting food preparation and distribution centers in Babol. Tests related to different food types were performed by laboratory experts. Data collection with a checklist: date and place of sampling, number of samples, type of food, type of test, compliance of results with standards. Data were analyzed by SPSS $_{22}$ and descriptive statistics, Chi-square and t-test.

Results: 1043 food samples were tested from 5 groups of dairy products, protein, cereals, vegetables and other food groups. The highest number of samples in the cereal group was 767 samples (73.53\%). In the cereal group, most samples were breads. The $\mathrm{pH}$ of $11.67 \%$ of breads and the salt in $21.49 \%$ of breads did not match the standard. The blankit (sodium hydrosulfite) on bread dough were negative. Moisture, gluten, ash and pH match with the standards in all flour samples. The results of microbial tests on sweets and ice cream showed that Escherichia coli and Staphylococcus aureus and Salmonella were negative. Enterobacter aerogenes was positive in $8.20 \%$ of sweets, mold and yeast were positive in $19.58 \%$. The results of microbial tests on buttermilk and yogurt, grilled meat and chicken sandwiches, vegetables and salads showed that bacteria Escherichia coli and Staphylococcus aureus and all microorganisms were negative. Mold tests were positive in $11.12 \%$ of juice samples.

Conclusions: The results showed that the foods and drinks supplied in food and drink preparation and distribution centers in Babol in 2019 were of good chemical and microbial quality. In some food groups the results of microbial and chemical testings were negative, i.e. without contamination. Less than $20 \%$ of products in the group of cereals and protein products did not match with the standards, which is a satisfactory result compared to other studies conducted in different cities of Iran. These good results for food quality can be explained bythe constructive performance of food health experts that made good controling, monitoring, and food health and hygiene education.

Keywords: Food hygiene, Food quality, Microbial and chemical contamination

\footnotetext{
*Correspondence: jafarian.551@gmail.com

${ }^{2}$ Health Services Management, Environmental Health Engineering, Health Department, Social Determinants of Health Research Center, Health Research Institute, Babol University of Medical Sciences, Babol, Iran Full list of author information is available at the end of the article
}

\begin{abstract}
Introduction
Food safety and hygiene means preventing food contamination with a variety of chemical toxicants such as heavy metals, pesticides, bacteria, viruses, parasites and fungi $[1,2]$. The World Health Organization identifies diseases caused by food contamination as a most important recent public health problem worldwide [3]. In this regard, the
\end{abstract}

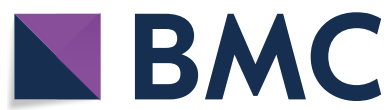

(c) The Author(s) 2021. Open Access This article is licensed under a Creative Commons Attribution 4.0 International License, which permits use, sharing, adaptation, distribution and reproduction in any medium or format, as long as you give appropriate credit to the original author(s) and the source, provide a link to the Creative Commons licence, and indicate if changes were made. The images or other third party material in this article are included in the article's Creative Commons licence, unless indicated otherwise in a credit line to the material. If material is not included in the article's Creative Commons licence and your intended use is not permitted by statutory regulation or exceeds the permitted use, you will need to obtain permission directly from the copyright holder. To view a copy of this licence, visit http://creativecommons.org/licenses/by/4.0/. The Creative Commons Public Domain Dedication waiver (http://creativeco mmons.org/publicdomain/zero/1.0/) applies to the data made available in this article, unless otherwise stated in a credit line to the data. 
slogan of 2018 environmental health was named (Global Food Safety and Sustainability) by the Information Federation of Environmental Health [4]. Factors involved in the foodborne diseases epidemic include inadequate food storage and environmental factors such as temperature and humidity, contamination of tools, preparation of food from unhealthy sources, poor personal hygiene and insufficient cooking time [5]. Common symptoms of food-borne diseases include diarrhea, fever, headache, vomiting, abdominal cramps, extreme tiredness, and sometimes blood in the stool [6, 7].

In developing countries such as Iran, however, there are no statistics on the incidence of food poisoning and infections. It can be expected that due to improper production, storage, distribution, and consumption of food, the prevalence of food poisoning and foodborne diseases is much higher than in developed countries. Iran is one of the developing countries. This study aims to evaluate the chemical and microbial quality of food in Northern Iran.

\section{Methods}

This article is cross-sectional study. Food sampling was performed by environmental health experts while visiting food preparation and distribution centers, including restaurants and grocery stores in urban and rural areas of Babol in 2019. Babol City located in Northern Iran and $18 \mathrm{~km}$ from the Caspian Sea with a population of 531,930, is the most populous city in the Province of Mazandaran. The height of the city is $2 \mathrm{~m}$ sea level [8].

After taking the samples, the environmental health experts transferred them to the laboratory of the Food and Drug Administration in Babol. Tests related to each type of food were performed by laboratory experts according to the type of chemical and microbial tests and applying standard methods [9].

The research tool was a checklist to record food information. Food information such as: date and place of sampling, number of samples, type of food (dairy products, protein, cereals, vegetables and other food groups), food product subgroups (cereals: flour, bread, dry and wet sweets), (dairy products: milk, yogurt, ice cream and buttermilk), (protein products: kebabs, meat sandwiches, chicken), (vegetables: salads and vegetables consumed in restaurants), type of test (microbial and chemical), types of chemical tests including $(\mathrm{pH}$, salt, color, acidity and polarity), types of microbial tests were including (mold, yeast, Salmonella, Escherichia coli and Staphylococcus, all microorganisms), match of results with National standards [9]. A number of food samples $(n=50)$ were removed from the checklist due to inconsistency with the research objectives and incomplete information.

Data were analyzed by $\operatorname{SPSS}_{22}$ and descriptive statistics, Chi-square, and $t$-test.

\section{Results}

In this study, 1043 food samples were tested in 5 groups of dairy products, protein, cereals, vegetables and other food groups. The highest number of samples in the cereals group was 767 samples (73.53\%). In the cereals group, most samples were breads.

\section{Results of chemical and microbial tests in cereal products}

540 breads were collected from urban (39.44\%) and rural (60.56\%) bakeries in Babol. The mean pH of breads was $5.96 \pm 0.46$, the lowest and highest $\mathrm{pH}$ in breads were 5 and 9.60, respectively. The mean $\mathrm{pH}$ of breads in urban was $6.29 \pm 0.35$ and in rural was $5.61 \pm 0.52$. $T$-test showed that the mean $\mathrm{pH}$ was not significantly related to bread sampling areas $(P=0.451, T=-1.285)$.

The mean salt in breads was $0.91 \pm 0.51$, the lowest and highest salts in breads were 0.11 and 4.09 , respectively. The mean salts of breads in urban areas was $0.90 \pm 0.52$ and in rural areas was $0.92 \pm 0.50$. $T$-test showed that the mean salt was significantly associated with breads sampling areas $(P=0.048, T=-0.419)$.

Breads in percentages of $88.33 \%$ and $78.51 \%$ were of acceptable quality within the standards in terms of $\mathrm{pH}$ and salt content, respectively. $\mathrm{pH}$ in $11.67 \%$ of breads and salt in the $21.49 \%$ of breads did not match the standard. The type of bread had a significant relationship with the positive results of $\mathrm{pH}$, so that the $\mathrm{pH}$ of Barbari bread was higher. The amount of salt with sampling seasons and the amount of salt had a significant relationship with the sampling area, so that the amount of salt was higher in summer and in rural areas (Table 1).

The blankit (sodium hydrosulfite) test of bread dough were negative. The mean ash test on 22 flour samples was $0.72 \pm 0.08 \mathrm{~g} / 100 \mathrm{~mL}$. The lowest and highest ash levels in flours were $0.5 \mathrm{~g} / 100 \mathrm{~mL}$ and $0.88 \mathrm{~g} / 100 \mathrm{~mL}$, respectively. The mean of gluten in flour samples was $28.209 \pm 1.319$. The lowest and highest gluten in flours were 26 and 30 , respectively. The mean $\mathrm{pH}$ in flour samples was $6.24 \pm 0.10$. The lowest and highest $\mathrm{pH}$ in flours were 6 and 6.4, respectively. The mean moisture of flour samples was $11.84 \pm 0.96 \mathrm{~g} / 100 \mathrm{~mL}$. The lowest and highest moisture in flours were $10.20 \mathrm{~g} / 100 \mathrm{~mL}$ and $12.77 \mathrm{~g} / 100 \mathrm{~mL}$, respectively. The moisture in the flours was significantly related to the sampling area with moisture of flours being higher in urban areas (Table 2).

Flour samples $(n=27)$ were tested for molds and other microorganisms. The test results showed that none of the flour samples tested positive for all microorganisms. There was no mold in 70.37\% of flours (Table 2).

Color test was performed on 59 samples of sweets. There was no color in 44 samples $(74.57 \%)$ and only 15 samples (25.43\%) had color. Color in the sweets had a significant relationship with sampling seasons (Table 3). 
Table 1 Results of chemical tests of bread in Babol-2019

\begin{tabular}{|c|c|c|c|c|c|c|c|c|c|}
\hline \multirow[t]{2}{*}{ Variables } & \multirow[t]{2}{*}{ Levels } & \multicolumn{2}{|c|}{$\mathrm{pH}$ test results } & \multirow[t]{2}{*}{$x^{2}$} & \multirow[t]{2}{*}{$P$ value } & \multicolumn{2}{|c|}{ Salt test results } & \multirow[t]{2}{*}{$x^{2}$} & \multirow[t]{2}{*}{$P$ value } \\
\hline & & Positive & Negative & & & Positive & Negative & & \\
\hline \multirow[t]{4}{*}{ Type of bread } & Barbari & $32(8)$ & $367(92)$ & 36.643 & 0.001 & $92(23.1)$ & 307 (76.9) & 4.879 & 0.181 \\
\hline & Taftoon & $26(31)$ & $58(69)$ & & & $18(21.4)$ & $66(78.6)$ & & \\
\hline & Lavash & $2(15.4)$ & $11(84.6)$ & & & $2(15.4)$ & $11(84.6)$ & & \\
\hline & Sangak & $3(6.8)$ & $41(93.2)$ & & & $4(9.1)$ & $40(90.9)$ & & \\
\hline \multirow[t]{4}{*}{ Sampling seasons } & Spring & $23(30.3)$ & $53(69.7)$ & 34.192 & 0.001 & $21(27.6)$ & $55(72.4)$ & 39.525 & 0.001 \\
\hline & Summer & $23(9.5)$ & $219(90.5)$ & & & $76(31.4)$ & 166 (68.6) & & \\
\hline & Autumn & $5(3.9)$ & $123(96.1)$ & & & $7(5.5)$ & $121(94.5)$ & & \\
\hline & Winter & $12(12.8)$ & $82(87.2)$ & & & $12(12.8)$ & $82(87.2)$ & & \\
\hline \multirow[t]{2}{*}{ Sampling area } & Urban & $28(13.1)$ & $185(86.9)$ & 0.746 & 0.388 & $30(14.1)$ & 183 (85.9) & 11.410 & 0.001 \\
\hline & Rural & 35 (10.7) & 292 (89.3) & & & $86(26.3)$ & $241(73.7)$ & & \\
\hline
\end{tabular}

Table 2 Results of chemical and microbial tests on bread dough and flour in Babol-2019

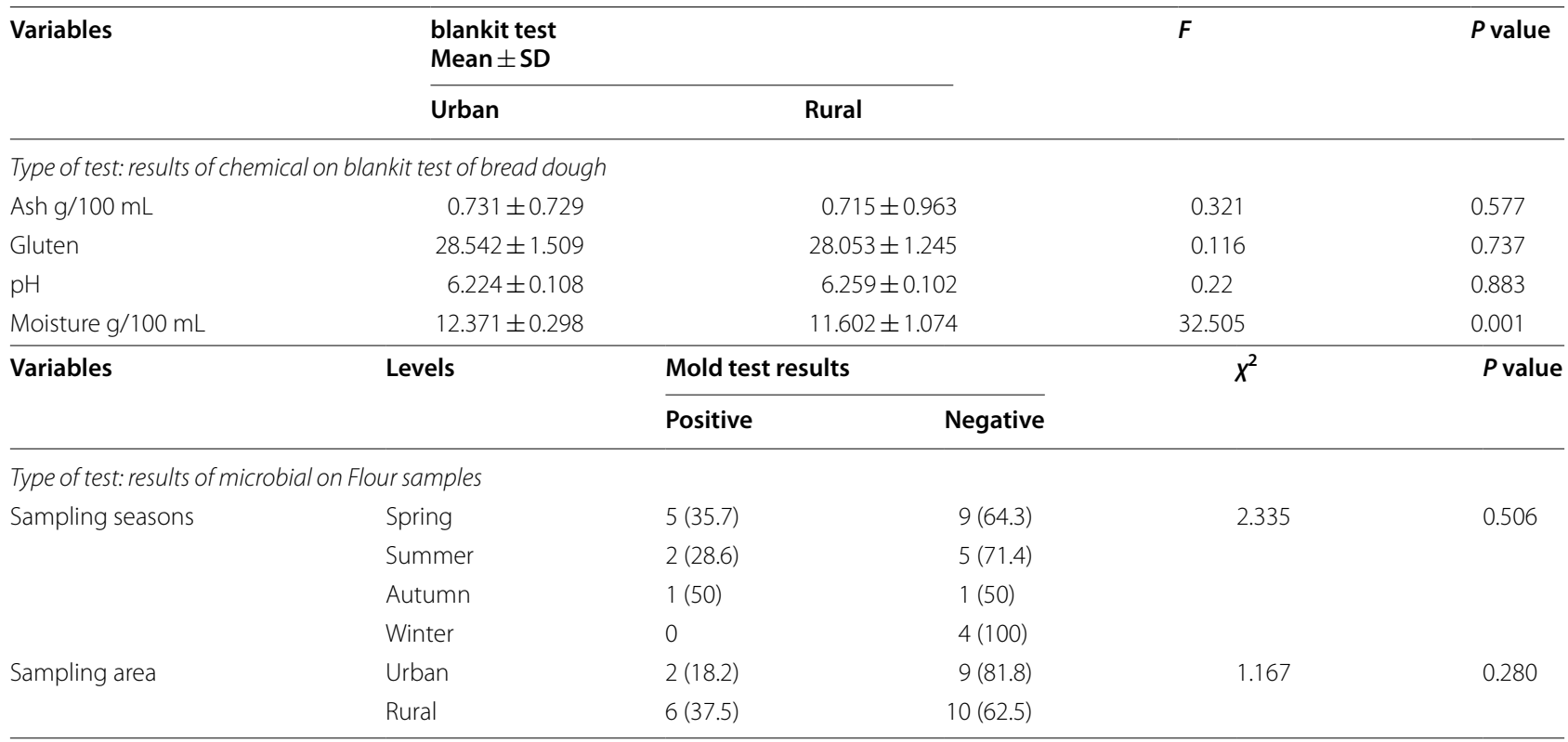

The results of microbial tests on 97 sweets showed that Escherichia coli and Staphylococcus aureus and Salmonella were negative. The results of Enterobacter tests were positive in 8 samples (8.24\%), mold and yeast were positive in 19 samples (19.58\%) (Table 3).

\section{Results of chemical and microbial tests in dairy products}

Out of 31 samples of ice cream and juices, $90.32 \%$ had not color and only $9.68 \%$ of the samples had color.

The results of microbial tests on 32 ice creams showed that Escherichia coli and Staphylococcus aureus were negative. Salmonella was negative in 31 ice cream (96.87\%) whereas it was detected in only 1 sample (3.13\%). Total microorganisms were negative in 23 samples (71.87\%) and positive in 9 samples (28.13\%).

Microbial tests on 18 juices showed that coliforms, total microorganisms, Salmonella, Staphylococcus aureus, Escherichia coli and yeasts were negative in the juices. Mold was negative in 16 juices $(88.88 \%)$ and mold was detected in only 2 samples (11.12\%).

Microbial tests on 30 buttermilk and yogurt types showed that Escherichia coli and Staphylococcus aureus and total microorganisms were negative.

Results of chemical and microbial tests in protein products Out of 31 samples of meat stews and grilled chicken, 22 samples (71\%) had no color. 23 samples of meat 
Table 3 Results of chemical and microbial tests on sweets in Babol-2019

\begin{tabular}{|c|c|c|c|c|c|c|c|c|c|}
\hline \multirow[t]{2}{*}{ Variables } & & \multirow[t]{2}{*}{ Levels } & & \multicolumn{3}{|l|}{ Color test } & \multirow{2}{*}{\multicolumn{2}{|c|}{$x^{2}$}} & \multirow[t]{2}{*}{$P$ value } \\
\hline & & & & Positive & \multicolumn{2}{|c|}{ Negative } & & & \\
\hline \multicolumn{10}{|c|}{ Type of test: results of color in sweets } \\
\hline \multirow{4}{*}{\multicolumn{2}{|c|}{ Sampling seasons }} & Spring & & $9(36)$ & \multicolumn{2}{|c|}{$16(64)$} & \multicolumn{2}{|l|}{8.315} & 0.040 \\
\hline & & \multicolumn{2}{|l|}{ Summer } & $1(6.7)$ & \multicolumn{2}{|c|}{14 (93.3) } & & & \\
\hline & & \multicolumn{2}{|l|}{ Autumn } & 0 & \multicolumn{2}{|c|}{$7(100)$} & & & \\
\hline & & \multicolumn{2}{|l|}{ Winter } & $5(41.7)$ & \multicolumn{2}{|c|}{$7(58.3)$} & & & \\
\hline \multirow{2}{*}{\multicolumn{2}{|c|}{ Sampling area }} & Urban & & $4(17.4)$ & \multicolumn{2}{|c|}{$19(82.6)$} & \multirow[t]{2}{*}{1.283} & & 0.257 \\
\hline & & Rural & & $11(30.6)$ & & & & & \\
\hline \multirow[t]{2}{*}{ Variables } & \multirow[t]{2}{*}{ Levels } & \multicolumn{2}{|l|}{ Mold } & \multirow[t]{2}{*}{$x^{2}$} & \multirow[t]{2}{*}{$P$ value } & \multicolumn{2}{|l|}{ Yeast } & \multirow[t]{2}{*}{$x^{2}$} & $P$ value \\
\hline & & Positive & Negative & & & Positive & Negative & & \\
\hline Type of test: results o & robial tests & on sweets & & & & & & & \\
\hline Type of sweets & Dry & $10(11.8)$ & $75(88.2)$ & 26.696 & 0.001 & $9(10.6)$ & $76(89.4)$ & 35.329 & 0.001 \\
\hline & wet & $9(75)$ & $3(25)$ & & & $10(83.3)$ & $2(16.7)$ & & \\
\hline Sampling seasons & Spring & $2(13.3)$ & $13(86.7)$ & 6.967 & 0.073 & $2(13.3)$ & $13(86.7)$ & 6.967 & 0.073 \\
\hline & Summer & $9(29)$ & $22(71)$ & & & $9(29)$ & $22(71)$ & & \\
\hline & Autumn & $8(24.2)$ & $25(75.8)$ & & & $8(24.2)$ & $25(75.8)$ & & \\
\hline & Winter & 0 & $18(100)$ & & & 0 & $18(100)$ & & \\
\hline Sampling areas & Urban & $4(9.1)$ & 40 (90.9) & 5.633 & 0.018 & $3(6.8)$ & $41(93.2)$ & 8.337 & 0.004 \\
\hline & Rural & $15(28.3)$ & $38(71.7)$ & & & $16(30.2)$ & $37(69.8)$ & & \\
\hline
\end{tabular}

sandwiches and grilled chicken were negative for coliforms, total microorganisms, Salmonella, Staphylococcus aureus and Escherichia coli. The mold test was negative in $67.74 \%$ of meat samples and positive in $32.26 \%$. Chisquare showed that different seasons had a significant relationship with mold positivity in meat samples $\left(P=0.034, \chi^{2}=8.695\right)$, the most positive results of mold in meat samples were in summer.

\section{Results of microbial tests on vegetable products}

Microbial tests on 9 samples of vegetables and salads from restaurants showed that all samples were negative for mold, coliforms, total microorganisms, Salmonella, Enterobacter, Staphylococcus aureus and Escherichia coli.

\section{Results of chemical and microbial tests on other food products}

Acidity and total polar material (TPM) tests were performed on 125 samples of frying oil used in confectioneries and restaurants. Tests on 113 oil in confectionery samples showed that the mean acidity was $0.14 \pm 0.15 \mathrm{~g} / 100 \mathrm{~mL}$, the minimum and maximum acidities were $0.02 \mathrm{~g} / 100 \mathrm{~mL}$ and $0.93 \mathrm{~g} / 100 \mathrm{~mL}$, respectively. The mean TPM was $11.63 \pm 3.10 \mathrm{mg}$, the minimum and maximum TPM were 8 and 23.50, respectively.

Tests on 12 oils used in restaurants showed that the mean acidity in oils was $0.21 \pm 0.212 \mathrm{~g} / 100 \mathrm{~mL}$, the minimum and maximum acidity were $0.02 \mathrm{~g} / 100 \mathrm{~mL}$ and $0.64 \mathrm{~g} / 100 \mathrm{~mL}$, respectively. The mean TPM was $12.54 \pm 4.01 \mathrm{mg}$, the minimum and maximum TPM were $8 \mathrm{mg}$ and $23.50 \mathrm{mg}$, respectively. The results of acidity and TPM tests on all oil samples taken from confectioneries and restaurants were negative.

\section{Discussion}

In this study, Bread as the dominant food has a major share in the consumption pattern of households in Iran. The per capita consumption of wheat and bread in Iran is about 24 and $300 \mathrm{~kg}$, respectively [10,11], so most of the food samples were breads. In this study, the $\mathrm{pH}$ was $\leq 6$ and for salt was less than one in breads. According to national standards, $\mathrm{pH}(\leq 6)$ and salt $(\leq 1.8 \%)$ are acceptable [9]. $78.51 \%$ of breads had no problem with salt and were matching the standards. In a study by Hagh Nazari et al. (2016) 5\% of breads had unsuitable $\mathrm{pH}$ and there was baking soda in breads [12]. In a study by Malakotian et al. (2003) showed that the $\mathrm{pH}$ and salt of breads were $5.4 \mathrm{~g}$ and $3.27 \mathrm{~g}$, respectively [13]. In this study, the $\mathrm{pH}$ level in $11.67 \%$ of breads were beyong permissable values, compared to the breads sampled in Rafsanjan, $22.33 \%$ (13), Yazd breads 12\% [14], had a pH beyond the standard, the results of the present study can provide good evidence that in the city of Babol, health experts have done 
successful work in controling, monitoring and providing health education.

In the present study, the mean moisture of the flours was $11.84 \pm 0.96 \mathrm{~g} / 100 \mathrm{~mL}$ and the mean ash was $0.72 \pm 0.08 \mathrm{~g} / 100 \mathrm{~mL}$. A study by Khoshakhlagh et al. (2015) showed that the mean moisture of flour was $14 \pm 0.004 \mathrm{~g} / 100 \mathrm{~mL}$ and the mean ash was $1.32 \pm 0.06 \mathrm{~g} / 100 \mathrm{~mL}$ [15]. A study by Nasehi et al. (2014) showed that the amount of ash in some samples of flour was more than the standard [16]. But in our study, the amount of ash in all flour samples was within the standards, indicating the production of quality bread in Babol.

In the present study, $25.43 \%$ of the sweets had color. In this study, $9.7 \%$ of ice cream and juices had color. A study by Rahimi et al. (2016) showed that $50.4 \%$ of food samples had color [17]. In a study by Asadi et al. (2019) showed that artificial colors were used in $42.9 \%$ of the foods offered in restaurants in Fasa [18]. Comparing the results of this part of the study with other mentioned studies shows that the food in Babol was in good condition and only a small percentage of the samples had color. But because some artificial colors in small quantities cause allergies and lead to tongue inflammation and hyperactivity disorders in children [19,20], it is suggested that more monitoring should be done in this sector and violators should be fined.

In this study, the results of microbial testing of sweets showed that Escherichia coli and Staphylococcus aureus and Salmonella were negative. Enterobacteriaceae were positive in $8.20 \%$, mold and yeast in $19.58 \%$ of sweets. Mold and yeast were more prevalent in wet sweets and rural areas. A study by Nasehinia et al. (2017) showed that $33.8 \%$ of the sweets had microbial contamination, of which mold and yeast contamination provided $21.7 \%$ and $11.4 \%$, respectively [21]. A study by Nikniaz et al. (2011) showed that $48.8 \%$ of the wet sweets samples were contaminated by Escherichia coli, 38.8\% with coliforms, 31.2\% with Staphylococcus aureus, and 70\% with yeasts [22]. In a study by Masoumalinejad et al. (2017) it was reported that high contamination of wet sweets sampled in spring was related to bacillus, mold and yeast and in summer these were related to yeast. In dry sweets, contamination was attributed to molds in spring, yeast and Bacillus in summer [23]. In the United Kingdom, more than 30\% of foodborne diseases were related to confectionery, with Staphylococcus being the most common contamination [24]. Because fungal spores are scattered in the air, they can contaminate sweets. Contamination of confectionery containers, contamination of distributors and fungal contamination of confectionery materials such as sugar and flour can lead to mold and yeast contamination in sweets, so to prevent contamination of pastries with mold and yeast, hygienic conditions must be observed.

\section{Conclusion}

The results showed that the food supplied in food preparation and distribution centers in Babol is of sufficient chemical and microbial quality, that in some food groups the results of microbial and chemical tests were completely negative. Less than $20 \%$ of products in the group of cereals and protein products did not match with National standards, which is a satisfactory result compared to other studies conducted in different cities of Iran. The good results related to food quality are explained by the fact Babol health experts in Babol have done a good control, monitoring and health education.

One of the strengths of this report is evaluation of chemical and microbial quality in different food groups. One of the study weaknesses were easy sampling and small number of food samples in some groups. The results of bread tests can be generalized to other bread samples due to the large volume of samples but the results of other food groups cannot be generalized.

\section{Abbreviations \\ WHO: World Health Organization; CDC: Centers for Disease Control and Pre- vention; UK: United Kingdom; SPSS: Statistical package for social science; TPM: Total polar material.}

\section{Acknowledgements}

The authors would like to thank the Vice-Chancellor of Research and Technology in Babol University of Medical Sciences for financial support (Project No. 9910014).

\section{Authors' contributions}

ZA and SJ designed the study, made final decisions on the inclusion of journal articles and extracted data from those and wrote and revised the manuscript. $\mathrm{SRH}, \mathrm{MR}, \mathrm{MM}, \mathrm{EE}$ and $\mathrm{PH}$ wrote and revised the manuscript. All authors read and approved the final manuscript.

\section{Funding}

This research benefited from the support of the Deputy of Research and Technology of the Babol University of Medical Sciences.

\section{Availability of data and materials}

The datasets used and analysed during the current study are available from the corresponding author upon reasonable request.

\section{Declarations}

Ethics approval and consent to participate

This study was approved and registered by the Code of Ethics (IR.MUBABOL. HRI.REC.1399.099)

\section{Consent for publication}

Not applicable.

\section{Competing interests}

The authors declare that they have no competing interests.

\section{Author details}

${ }^{1}$ Social Determinants of Health Research Center, Health Research Institute, Babol University of Medical Sciences, Babol, Iran. ${ }^{2}$ Health Services Management, Environmental Health Engineering, Health Department, Social Determinants of Health Research Center, Health Research Institute, Babol University of Medical Sciences, Babol, Iran. ${ }^{3}$ Deputy of Food and Drug, Babol University 
of Medical Sciences, Babol, Iran. ${ }^{4}$ Director of the Center for Environmental and Occupational Health, Deputy of Health, Babol University of Medical Sciences, Babol, Iran.

Received: 8 January 2021 Accepted: 7 September 2021

Published online: 20 September 2021

\section{References}

1. Stratev D, Odeyemi OA, Pavlov A, Kyuchukova R, Fatehi F, Bamidele FA. Food safety knowledge and hygiene practices among veterinary medicine students at Trakia University, Bulgaria. J Infect Public Health. 2017;10(6):778-82. https://doi.org/10.1016/j.jiph.2016.12.001.

2. Lam H-M, Remais J, Fung M-C, Xu L, Sun SS-M. Food supply and food safety issues in China. Lancet. 2013;381(9882):2044-53. https://doi.org/10. 1016/S0140-6736(13)60776-X.

3. WHO. Food safety and food-borne illness.2007; [Fact sheet No. 237]. Available at http//:www.who.int/mediacentre/factsheets/fs237/en/index.html. Accessed 17 Mar 2007.

4. https://www.ifeh.org/wehd/2018/World\%20Environmental\%20Health\% 20Day\%202018.pdf

5. Surveillance for foodborne disease outbrakes United States 1998-2002. MMWR Surveill Summ 2006:55:1-42.

6. Mritunjay SK, Kumar V. A study on prevalence of microbial contamination on the surface of raw salad vegetables. 3 Biotech. 2017;7(1):13. https:// doi.org/10.1007/s13205-016-0585-5.

7. Whitney BM, Mainero C, Humes E, Hurd S, Niccolai L, Hadler JL. Socioeconomic status and foodborne pathogens in Connecticut, USA, 2000-2011. Emerg Infect Dis. 2015;21:1617-24.

8. Aghalari Z, Amouei A, Jafarian S. Determining the amount, type and management of dental wastes in general and specialized dentistry offices of Northern Iran. J Mater Cycles Waste Manag. 2020;22:150-8. https://doi. org/10.1007/s10163-019-00924-3.

9. Institute of Standards and Industrial Research of Iran.2002, 2005, 2007, 2012, 2013, 2014. http://www.isiri.gov.ir. Accessed 8 Feb 2020.

10. Abdollahi M, Mohammadi F, Houshiar-Rad A, HajiFaragi M, Esfarjani F. Shares of energy and nutrients intake from subsidized food items in Iranian households in different socio-economic status. Iran J Nutr Sci Food Technol. 2011;6(1):43-56 (Abstract in English).

11. Sakizadeh M, Ghorbani H. Concentration of heavy metals in soil and staple crops and the associated health risk. Arch Hyg Sci. 2017;6(4):303-13.
12. Hagh Nazari S, Zarin Ghalami S. Qualitative features of yeast used in Zanjan's bakeries. FSCT. 2016;13(58):31-45.

13. Malakoutian M, Loloei M. Investigation of bread quality and hygienic condition of Rafsanjan's bakeries. J Rafsanjan Univ Med Sci. 2003;2(3):1-6.

14. Kargar $\mathrm{MH}$, Mozafari $\mathrm{H}$. An investigation on bread in Yazd city. J Yazd Shahid Sadougi Univ Med Sci. 2001;5(2):16-23.

15. Khoshakhlagh Kh, Hamdami N, Shahedi M, Soleimanian S. Study of quality and microbial characteristics of part-baked Sangak bread packaged in modified atmosphere during storage. FSCT. 2015;12(46):29-39.

16. Nasehi B, Tahanejad M. Characteristics of the chemical, sensory and microbials of flours in Khuzestan. FSCT. 2014;11(45):77-84.

17. Rahimi S, Kiani M, Ezati P, Pourmohammadi B, Biabani J, Torabi H, Khazaei Z. Prevalence of colors used in Saffronal foods of Yazd using thin layer chromatography (TLC) in 2015. Navid No. 2016;19(62):1-7. https://doi. org/10.22038/nnj.2016.7371.

18. Asadi S, Sayadi M, Khalighain S, Hashemi S, Allahverdi G. The study of the frequency of dyes used in food products delivered at Fasa restaurants using thin layer chromatography and spectrophotometric methods in 1397. J Fasa Univ Med Sci. 2019;9(1):1306-13.

19. Jonnalagadda PR, Rao P, Bhat RV, Nadamuni NA. Type, extent and use of colours in ready-to-eat (RTE) foods prepared in the non-industrial sector-a case study from Hyderabad, India. Int J Food Sci Technol. 2004;39(2):125-31.

20. Kleinman RE, Brown RT, Cutter GR, DuPaul GJ, Clydesdale FM. A research model for investigating the effects of artificial food colorings on children with ADHD. Pediatrics. 2011;127:e1575-84

21. Nasehinia H, Rahimi S, Kiani M, Ghaneapur MR, Ajam F. Assessment of microbial contamination of traditional sweets in Yazd, Iran, in 2015. J Health Res Commun. 2017;2(4):26-34.

22. Nikniaz Z, Mahdavi R, Jalilzadeh H, Vahed JM. Evaluation of microbial contamination in cream filled pastries distributed in Tabriz confectionaries. J Food Technol Nutr. 2011;8(1):66-71 (Persian).

23. Masoumalinejad Z, Zinatizadeh MR, Meybodi SM. Isolation of microbial contamination of sweets in Sirjan City. JPM. 2017;4(1):56-62.

24. Smith JP, Daifas DP, El-Khoury W, Koukoutsis J, ElKhoury A. Shelf life and safety concerns of bakery products-a review. Crit Rev Food Sci Nutr. 2004;44(1):19-55.

\section{Publisher's Note}

Springer Nature remains neutral with regard to jurisdictional claims in published maps and institutional affiliations.
Ready to submit your research? Choose BMC and benefit from:

- fast, convenient online submission

- thorough peer review by experienced researchers in your field

- rapid publication on acceptance

- support for research data, including large and complex data types

- gold Open Access which fosters wider collaboration and increased citations

- maximum visibility for your research: over $100 \mathrm{M}$ website views per year

At BMC, research is always in progress.

Learn more biomedcentral.com/submissions 